\title{
Role of Apoptosis in Rabies Viral Encephalitis: A Comparative Study in Mice, Canine, and Human Brain with a Review of Literature
}

\author{
M. S. Suja, ${ }^{1}$ Anita Mahadevan, ${ }^{1}$ S. N. Madhusudana, ${ }^{2}$ and S. K. Shankar ${ }^{1}$ \\ ${ }^{1}$ Department of Neuropathology, National Institute of Mental Health and Neurosciences (NIMHANS), Bangalore 560029 , India \\ ${ }^{2}$ Department Neurovirology, National Institute of Mental Health and Neurosciences (NIMHANS), Bangalore 560 029, India
}

Correspondence should be addressed to Anita Mahadevan, anita_mahadevan@yahoo.com

Received 16 October 2010; Accepted 9 June 2011

Academic Editor: C. Sundaram

Copyright (C) 2011 M. S. Suja et al. This is an open access article distributed under the Creative Commons Attribution License, which permits unrestricted use, distribution, and reproduction in any medium, provided the original work is properly cited.

\begin{abstract}
To evaluate the role of apoptosis in rabies encephalitis in humans and canines infected with wild-type street virus, in comparison with rodent model infected with street and laboratory passaged CVS strain, we studied postmortem brain tissue from nine humans, six canines infected with street rabies virus, and Swiss albino mice inoculated intramuscularly (IM) and intracerebrally (IC) with street and CVS strains. Encephalitis and high rabies antigen load were prominent in canine and human brains compared to rodents inoculated with street virus. Neuronal apoptosis was detectable only in sucking mice inoculated with CVS strain and minimal in street virus inoculated mice. In a time point study in suckling mice, DNA laddering was noted only terminally (7 days p.i.) following IC inoculation with CVS strain but not with street virus. In weanling and adult mice, apoptosis was restricted to inflammatory cells and absent in neurons similar to human and canine rabies-infected brains. Absence of neuronal apoptosis in wild-type rabies may facilitate intraneuronal survival and replication while apoptosis in inflammatory cells prevents elimination of the virus by abrogation of host inflammatory response.
\end{abstract}

\section{Introduction}

In Asia, canine rabies continues to be a serious public health problem causing large number of animal and human deaths. According to WHO estimates, 50,000 human deaths are reported worldwide every year [1], the majority from Asia and Africa, and $60 \%$ of them are from India alone [2]. Humans and canines acquire the infection by the introduction of virus-laden saliva following bite of a rabid animal [3] or rarely following mucosal exposure [4]. On gaining receptor-mediated entry into the neuron, the virus replicates and disseminates in the central nervous system by fast axonal transport along neuroanatomical connections. Clinically the disease manifests, either as furious (encephalitic) or paralytic (dumb) form of rabies, twothird of the victims suffering from furious form [5]. Unlike other viral encephalitides, examination of the brain reveals surprisingly minimal pathological alterations, in contrast to the dramatic clinical symptomatology.

Most studies on neuropathogenesis of rabies have employed animal models using laboratory-adapted viral strains. In natural hosts infected with virulent "street virus" strains, the pathogenetic mechanism mediating the disease is not well characterized. Experimental studies suggest dysregulation of neurotransmitters and ion channels or altered host immune responses as the cause of clinical symptomatology [6], but the cause of invariable fatality remains uncertain.

Recent reports suggest that viruses cause death of infected cells by apoptosis [7-10]. Apoptosis has also been implicated in pathogenesis of rabies, based on in vitro studies on neuronal cell lines as well as experimental studies in mice inoculated with laboratory-adapted virus strains $[11,12]$.

In natural hosts like bats (Artibeus jamaicensis bats) however, when infected with laboratory-adapted CVS-24 strain of rabies virus, Reid and Jackson failed to detect apoptosis in the neurons [13]. Yan et al. inoculating wildtype virus (silver-haired bat rabies virus) into experimental mice reported very few TUNEL-positive neurons, despite the presence of clinical signs of the disease, suggesting that apoptosis may not be an essential neuropathogenic mechanism [14]. In an HIV-1 positive individual bitten by a rabid dog, three months prior to clinical manifestation 
of HIV-1, apoptosis was observed in neurons, macrophages, microglial cells, and oligodendrocytes in postmortem brain that was attributed solely to rabies virus infection and not considered to be induced by HIV-1 [15]. Jackson et al. evaluated the morphological features of neuronal apoptosis in postmortem brain tissue from 12 cases of human rabies collected from four different countries and suggested that neuronal apoptosis does not play an important role in human rabies encephalitis [16]. Apoptosis restricted to few inflammatory cells, but not neurons or glia in cases of canine rabies following natural infection with wild-type virus, was reported from our laboratory in a previous study [17].

To probe further the role of apoptosis in rabies infection, in the present communication, we compared the pathological features noted in natural hosts (human and canine) infected by street virus with the findings in susceptible swiss albino adult, weanling, and suckling mice, inoculated by intramuscular (IM) and intracerebral (IC) route with street virus (primary isolate from a canine brain) as well as laboratory-adapted CVS strains of rabies. Though no case of new born humans infected with rabies virus has been recorded and intracerebral inoculation does not reflect natural infection, these two events in mice are studied to enable comparison with other routes and ages. Histopathological features and neuroanatomical distribution of rabies viral antigen were examined in the human, canine subjects, and animal models. The phenomenon of apoptosis was evaluated by DNA fragmentation and TUNEL assay.

\section{Materials and Methods}

2.1. Experimental Mice. Swiss albino \{suckling mice (two days old), weanling (21 days old), and adults (3 months) obtained in batches from the same litter (both sexes) were sourced from the Central Animal Research Facility, National Institute of Mental Health and Neurosciences, Bangalore, South India. The animals were housed in spacious cages maintained at ambient temperature $\left(24^{\circ} \mathrm{C}\right)$ with $12 \mathrm{hr}$ light and dark cycles and access to pelleted food and water ad libitum. For experiments on suckling mice, litters of 10-15 animals were used. Weanling and adult test animals received $0.03 \mathrm{~mL}$ and suckling mice $0.01 \mathrm{~mL}$ of pretitered rabies virus (street virus and CVS strain-1000LD $\mathrm{LD}_{50}$ dilution), respectively. Suckling, weanling, and adult mice inoculated, respectively, with $0.01 \mathrm{~mL}$ and $0.03 \mathrm{~mL}$ of the vehicle, phosphate buffered saline served as negative controls. The study was approved by the Institutional Ethics Committee.

\subsection{Virus Strain}

(a) Stock of laboratory-adapted fixed rabies virus strain, CVS 11, was obtained as lyophilized mouse brain homogenate from the Central Research Institute, Kasauli, Himachal Pradesh, North India. CVS virus was prepared by passaging the rabies virus in suckling mouse brain as described previously [18]. (b) The brain tissue (hippocampus and cerebellum) from a confirmed case of furious rabies in a canine was homogenized in phosphate-buffered saline, and 20\% suspension was aliquoted and stored at $70^{\circ} \mathrm{C}$ till use (primary isolate). This formed the source for "street virus" strain.

2.3. Experimental Design. Batches of adult, weanling and suckling mice were used for intramuscular (IM, $n=3$ ) and intracerebral (IC, $n=3$ ) inoculation with street and CVS strain of rabies virus, respectively. Intramuscular inoculation was administered in the right thigh. The intracerebral inoculation was at a point midway between the left ear and saggittal suture, into the parietal area (roughly corresponding to the sensory motor cortex). The animals in each group were monitored daily for 21 days for clinical features and the evolution of symptoms of rabies till they succumbed (Table 1). When the animals were found moribund and immobile with labored breathing indicating imminent death, they were euthanised by ether inhalation. Fresh brain tissues were collected from the frontal cortex for DNA laddering, a marker of apoptosis and immunoflourescence for rapid diagnosis. For histopathology, immunocytochemistry and TUNEL staining, 10\% neutral-buffered formalin-fixed brains were used.

Human brain tissues $(n=9)$ collected at autopsy (following informed consent from close relatives), from confirmed cases of rabies and stored at the Human Brain Tissue Repository (Brain Bank), Department of Neuropathology, National Institute of Mental Health and Neurosciences, Bangalore were utilized for the study. They included both fresh (stored at $-80^{\circ} \mathrm{C}$ ) and formalin-fixed brain tissues from frontal, temporal, hippocampus, cerebellum, and medulla oblongata. Fresh brains from euthanised canines $(n=6)$ with a diagnosis of furious rabies were collected from the Department of Veterinary Pathology, University of Veterinary Sciences, Hebbal, Bangalore. Fresh canine brain samples from frontal, temporal cortex, and cerebellum were frozen at $-80^{\circ} \mathrm{C}$ and the remaining were fixed in $10 \%$ buffered formalin for histological evaluation and immunohistochemistry to demonstrate viral antigen and TUNEL staining.

2.4. Histopathology. Standard haematoxylin-eosin staining on histological sections (five-micron thick), was examined for pathomorphological changes including microglial proliferation, perivascular inflammation, neuronophagia, and presence of intraneuronal eosinophillic Negri bodies in human, canine, and rodent brains in different anatomical areas were recorded. Cresyl-violet-stained adjacent sections were screened at high magnification $(\times 40$ objective $)$ for nuclear pyknosis and apoptotic bodies in neurons, glia, and vascular endothelial cells.

2.5. Immunocytochemistry for the Detection of Rabies Viral Nucleocapsid Antigen. Representative sections from different neuroanatomical areas from human, canine, and rodent were immunostained with polyclonal antibody to rabies viral nucleocapsid (1:1500 dilution, specificity of the antibody was established by SDS-PAGE and western blot, which 
TABLE 1: Comparison of the incubation period (IP) and duration of illness (DOI) with different routes of inoculation and strains of rabies virus.

\begin{tabular}{|c|c|c|c|c|}
\hline \multirow{2}{*}{\multicolumn{2}{|c|}{ Type of Virus and Route of inoculation }} & \multicolumn{3}{|c|}{ Incubation period (IP) and duration of illness (DOI) } \\
\hline & & $\begin{array}{l}\text { Suckling mice } \\
\text { (Age: } 0-2 \text { days) }\end{array}$ & $\begin{array}{l}\text { Weanling mice } \\
\text { (Age: } 21 \text { days) }\end{array}$ & $\begin{array}{c}\text { Adult mice } \\
\text { (Age: } 3 \text { months) }\end{array}$ \\
\hline \multirow{3}{*}{ Street } & Intracerebral & & & \\
\hline & IP & $8-10$ days & $6-8$ days & $6-8$ days \\
\hline & DOI & $24 \mathrm{hrs}$ & $24 \mathrm{hrs}$ & $24 \mathrm{hrs}$ \\
\hline \multirow{3}{*}{ CVS } & Intracerebral & & & \\
\hline & IP & $\leq 6$ days & $4-6$ days & $4-6$ days \\
\hline & DOI & $48-72 \mathrm{hrs}$ & $48-72 \mathrm{hrs}$ & $48-72 \mathrm{hrs}$ \\
\hline \multirow{3}{*}{ Street } & Intramuscular & Not done & & \\
\hline & IP & & $20-25$ days & $20-25$ days \\
\hline & DOI & & $24 \mathrm{hrs}$ & $24 \mathrm{hrs}$ \\
\hline \multirow{3}{*}{ CVS } & Intramuscular & Not Done & & \\
\hline & IP & & $8-10$ days & $8-10$ days \\
\hline & DOI & & $48-72 \mathrm{hrs}$ & $48-72 \mathrm{hrs}$ \\
\hline
\end{tabular}

Incubation period (IP): from bite to onset of clinical symptoms.

Duration of illness (DOI): from onset of clinical manifestation to death.

showed a single discrete band at the molecular weight $57 \mathrm{kDa}$, corresponding to rabies nucleoprotein) by standard indirect immunoperoxidase method. Appropriate negative controls (brain sections from an uninfected dog, mouse, and human brain and infected rabid dog brain treated identically but omitting the primary antibody) and positive controls (confirmed case of dog rabies, human rabies, and suckling mouse brain inoculated with rabies virus) were employed in each run to monitor the efficacy of the immunostaining process. The histopathological features and the extent of viral antigen distribution in different areas in the brain were graded semiquantitatively. Also representative sections from different neuroanatomical areas of human brain were immunostained with CD68 (Monoclonal, Biogenex, Calif, USA), marker for identifying macrophages/activated microglia.

2.6. DNA Laddering to Detect Apoptosis in the Brain. DNA was extracted from the fresh frozen rabies-virus-infected mouse brains (IC and IM inoculated suckling, weanling, and adult mice, three animals in each group), canine brain (hippocampus $(n=6)$ ), human brain (frontal, temporal, hippocampus, and medulla oblongata $(n=9)$ ) by the standard phenol-chloroform DNA extraction method. The extracted DNA was analyzed on agarose gel electrophoresis along with the molecular weight markers. Tissues from uninfected mice and canine brains and human brains with no evidence of rabies infection (brain collected from victims of road traffic accidents and stored) treated under similar conditions served as negative controls.

\subsection{Temporal Evolution of Apoptosis in Suckling Mouse Brain} Infected Intracerebrally with CVS Strain of Rabies Virus. Fresh brains from suckling mice infected intracerebraly with CVS strain of rabies virus were harvested at different time points-day 0, 24, 48, 72, 96, 120, $144 \mathrm{hrs,} \mathrm{and} \mathrm{DNA} \mathrm{was}$ extracted by standard phenol-chloroform extraction method and was analyzed by agarose gel electrophoresis.

2.8. In Situ TUNEL ASSAY for the Detection of Apop-tosis. To detect apoptotic nuclei, TUNEL (terminal deoxynucleotidyltransferase-mediated dUTP nick end labeling) staining was carried out using commercially available kit (ROCHE) as recommended by the manufacturer with appropriate positive and negative controls as previously described [17].

Double labeling for viral antigen and apoptosis could not be done for technical reasons, and; hence, immediate serial sections were stained and evaluated.

\section{Results}

The evolution of clinical signs (incubation period, IP) was earlier in mice infected with CVS strain compared to street virus, irrespective of the route of inoculation (Table 1). Mice inoculated with street virus had longer incubation period (8-10 days following IC inoculation and 20-25 days following IM inoculation), but the rate of disease progression was relatively rapid ( $24 \mathrm{hrs}$ versus $48-72 \mathrm{hrs}$ ). Intramuscular inoculation with street virus caused paralysis of hind limbs followed by fore limbs. Following intracerebral inoculation of street virus, mice manifested ruffling of fur, hump back followed by limb paralysis within 6-8 days and survived for 48-72 hrs after the onset of symptoms.

Inoculation (IC or IM) with CVS strain of rabies virus produced similar symptomatology as with street virus, but of shorter incubation period, (8-10 days with IM and 4-6 days with IC route).

Neuropathological changes (perivascular inflammation and microglial reaction) in natural hosts (human, canine) 


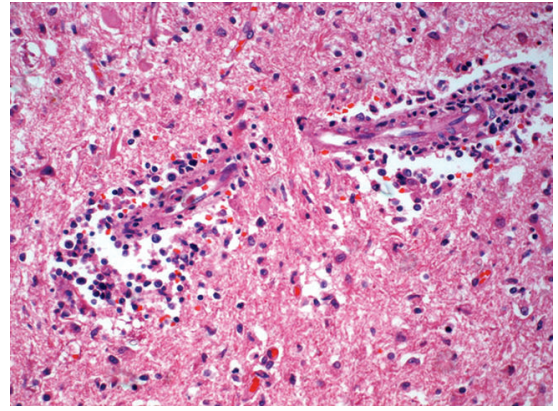

(a)

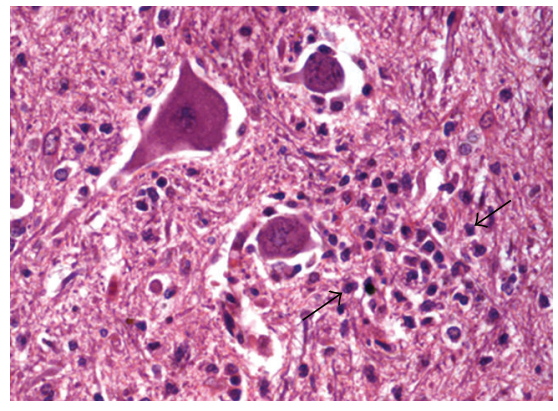

(c)

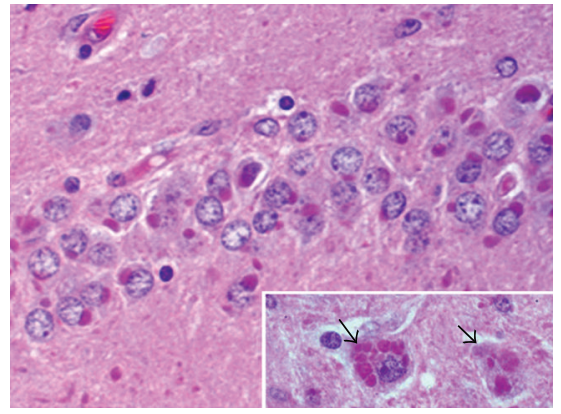

(b)

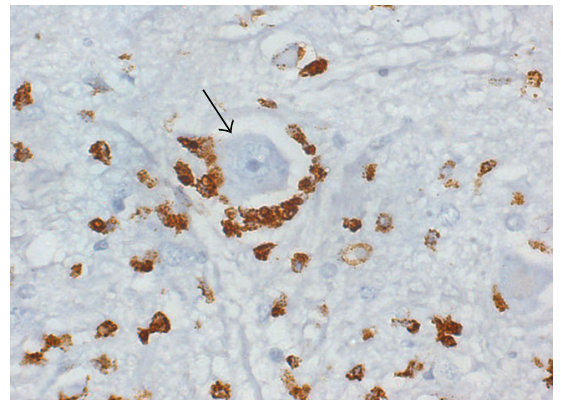

(d)

Figure 1: Human rabies viral encephalitis, 15 years/male, incubation period: 6 mon. Section from medulla oblongata showing dense perivascular cuffing of lymphomononuclear cells (a). Multiple Negri bodies are seen within granule neurons of hippocampal dentate gyrus (b). Inset shows multiple Negri bodies in hippocampal pyramidal neurons (b, inset, arrow). Anterior horn cells in the cervical segment of spinal cord are surrounded by microglial cells (c) Immunoreactive to CD68 (arrow, d). Note prominent nucleolus in the neuron reflecting viability. (a): $\mathrm{HE} \times 120$; (b): $\mathrm{HE} \times 360$; (b inset): $\mathrm{HE} \times 360$; C: $\mathrm{HE} \times 300$; D: Immunoperoxidase, CD68 $\times 300$.

were more extensive than those in rodent brains (Figures $1(\mathrm{a})-1(\mathrm{c}))$. Variable degree of Negri body formation was seen depending on the incubation period (Figure 1(d)). In mice, perivascular inflammation, microglial nodule formation and negri bodies were more frequent in street-virus-infected mice, irrespective of route of inoculation. In CVS inoculated mice (IC \& IM), perivascular inflammation and microglial reaction were mild while vacuolation of the neuronal soma was a striking feature. Negri bodies were undetectable. Suckling mice showed the least degree of inflammation.

Distinct differences were evident in the pattern and topography and the pattern of rabies viral antigen distribution in mice inoculated with street virus versus CVS strain (Table 2). In general, following street virus inoculation, widespread distribution of rabies viral antigen with a caudocranial gradient was observed by immunostaining. The highest concentration of antigen was seen in hippocampus (Figure 3(f)), thalamus, hypothalamus, amygdala, olfactory cortex, and cingulate gyrus while frontoparietal motor area as well as basal ganglia showed moderate number of infected neurons. As predictable, the quantum of viral antigen was considerably more following intracerebral route of inoculation. Within neurons, the viral antigen was seen aggregated into multiple globular masses (Figure $3(\mathrm{~h})$ ) with extensive dendritic spread $(+++)$. In contrast, following inoculation with CVS strain (IM or IC) of rabies virus, weanling and adult mice showed diffuse cytoplasmic labeling with minimal dendritic spread $(+)$ and extensive neuronal vacuolation. Neuroanatomically, the viral antigen was found mostly localized to specific sites like the ventral group of thalamic nuclei, hypothalamus, hippocampus (Figures 3(a) and $3(\mathrm{~d})$ ), and brainstem.

Topographical distribution of rabies viral antigen in the brain of naturally infected dogs and humans (street virus, peripherally inoculated by the animal bite) was diffuse and intraneuronal in almost all the anatomical areas (Figures $4(\mathrm{a})$ and $4(\mathrm{~d}))$. Among the supratentorial structures, there was striking involvement of the lateral and ventral group of thalamic nuclei and the basal ganglia in addition to the limbic structures. Overall the highest antigen load was noted in cerebral hemispheres and along the brain stem.

High load of viral antigen irrespective of incubation period was noted in large neurons of reticular formation, vagal and hypoglossal nuclei. The pattern and morphology of antigen deposits were similar to that of mouse inoculated with street virus, forming multiple Negri bodies. In addition to considerable viral load in the neurons in natural hosts (humans and canines), antigen was also found in the oligodendrocytes and long cytoplasmic processes of the fibrous astrocytes in many areas, but significantly less in mice inoculated with two different strains of rabies virus and two different routes of inoculation suggesting variable permissiveness of neurons and glia in different species. 
TABLE 2: Pathological features in mouse brain following inoculation with different strains of rabies virus with different routes of inoculation.

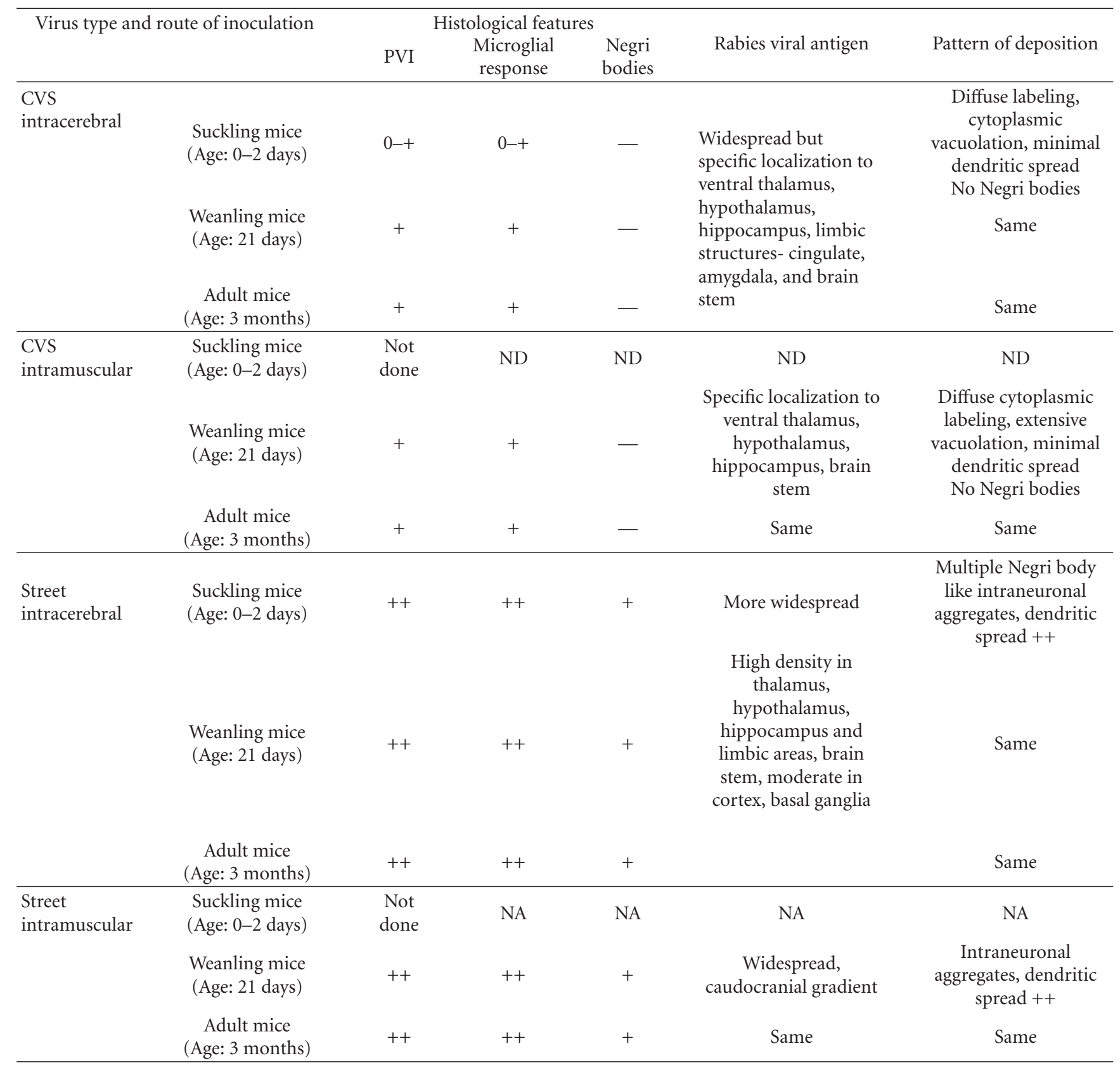

Abbreviations used: PVI: perivascular inflammation, ND: not done, NA: not available.

Detailed neuroanatomical distribution of the viral antigen and immunophenotyping of the inflammatory cells will be presented separately.

Phenotypic expression of apoptosis with cresyl violet staining was evident only in CVS-virus-inoculated suckling mice but not in weanling or adult mice nor in street-virusinoculated mice. Evidence of neuronal apoptosis was found in Ammon's horn neurons of hippocampus, as well as in the thalamus, hypothalamus, and cerebral cortex. Natural hosts (Human and Canine) did not demonstrate apoptosis in frontal, temporal, hippocampal regions, or in medulla oblongata.
DNA fragmentation (180-200 bp) and laddering confirmed the presence of apoptosis in suckling mouse brains infected with CVS strain of rabies virus. In the streetvirus-infected mice, and sham-infected animals as well as in human and canine brains, no apoptosis was demonstrable (Figures 2(a), 2(b), and 2(c)).

Temporal evolution of apoptosis was noted in suckling mouse brain infected with CVS strain of rabies virus but not street virus. In a time point study, DNA laddering indicative of apoptosis was observed in CVS-strain-infected mouse brains only terminally in the disease process on the 6th day ( $144 \mathrm{hrs}$ ) postinoculation, while the brain at earlier time 


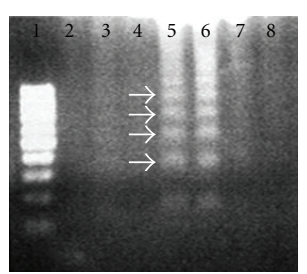

Lane 1: 100 bp ladder,

Lane 2: Normal mouse brain (uninfected)

Lane 3, 4: Suckling mouse brain infected with street virus

Lane 5, 6: Suckling mouse brain infected with CVS strain

Lane 7: Weanling mouse brain infected with street strain

Lane 8: Weanling mouse brain infected with CVS virus

(a)

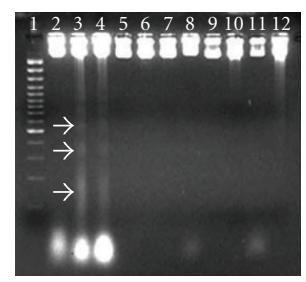

Lane 1: 100 bp ladder,

Lane 2: Normal mouse brain (uninfected)

Lane 3, 4: Suckling mouse brain (CVS)

Lane 5: Normal dog brain

Lane 6, 7, 8: Rabid dog brain

Lane 9: Normal human brain

Lane 10, 11, 12: Infected human brain

(c)

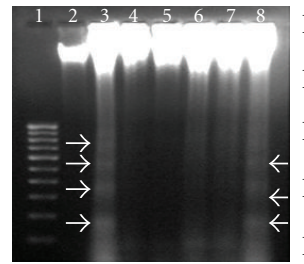

Lane 1: 100 bp ladder,

Lane 2: Normal mouse brain (uninfected)

Lane 3, 8: Suckling mouse brain (CVS)

Lane 4, 5: Adult mouse brain (CVS)

Lane 6, 7: Adult mouse brain (Street)

(b)

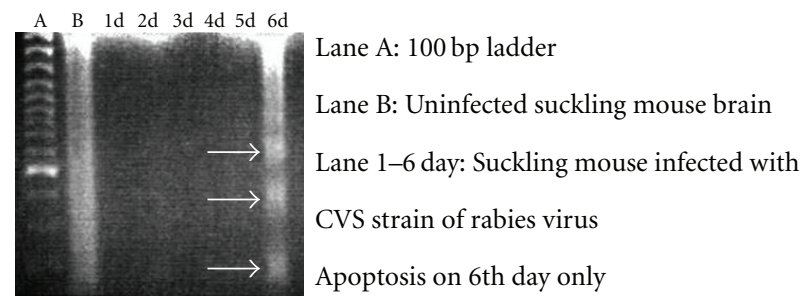

(d)

Figure 2: DNA laddering in Mouse brain. (a) DNA laddering (arrows) is seen only in suckling mouse brain infected with CVS strain of rabies virus (lanes $5 \& 6$ ). No laddering seen in street-virus-infected suckling mouse brain (lanes $3 \& 4$ ) and weanling adult mouse brain infected with street (lane 7) and CVS strain (lane 8) of rabies virus. (b) DNA laddering (arrows) in suckling mouse brain infected with CVS strain of rabies virus (lanes $3 \& 8$ ) and absence of laddering in street-virus-infected adult mouse brain infected with CVS and street strain of rabies virus. (c) DNA laddering (arrows) in suckling mouse brain infected with CVS strain of rabies virus and absence of laddering in street-virus-infected dog brain and human brain. (d) DNA laddering (arrows) in suckling mouse brain infected with CVS strain of rabies virus-time point study. DNA laddering exhibited only on the 6th day P.I.

points $(0,24,48,72,96,120 \mathrm{hrs})$ and uninfected mouse brain did not show a similar phenomenon, reflecting that apoptotic fragmentation of nuclear DNA was a terminal event (Figure $2(\mathrm{~d})$ ).

Terminal deoxynucleotidyltransferase-mediated dUTP Nick End Labeling (TUNEL) positive apoptotic cells were detected widely distributed in suckling mice brain inoculated with CVS strain of rabies virus only and not in street-virusinoculated ones or in naturally infected human and canine brain (Figure 3(b)). TUNEL-positive neurons were seen in all layers of the cerebral cortex, cingulate gyrus, Ammon's horn in hippocampus, and neurons in the thalamic, hypothalamic regions. In addition to neurons, the inflammatory cells lining the meninges, ependymal cells lining the ventricle, cells of the choroids plexus, and occasional glial and microglial cells in the cortex and white matter also showed labeling (Figure 3(c)). However, the endothelial cells lining the blood vessels were negative. Street-virus-infected suckling mice revealed TUNEL labeling of occasional microglial cells in the cerebral cortex and brain stem.

In the weanling and adult mice inoculated with CVS or street strain of rabies virus (IC and IM), neuronal cells failed to show apoptotic TUNEL immune labeled cells, while a few inflammatory cells, oligodendroglia, and astrocytic cells revealed occasional TUNEL labeling (Figures 3(e), 3(g), and 3(i)). Sham-infected animals (adult or neonatal) did not show apoptotic labeling.

In canine brains, no neuronal labeling was seen in any of the anatomical areas studied. But several microglial cells in the perivascular zone, endothelial cells lining the blood vessels, and the glial cells in the white matter had labelling by the TUNEL technique (Figure $4(\mathrm{~b})$ ). The labeling of inflammatory cells was significantly high in all the canine brains examined compared to mice or human brains (Figure 4(c)). In canine brains, CD68-positive macrophages, surrounding the partially digested neurons and microglial nodules in the vicinity, showed TUNEL labeling suggesting phagocytosis of apoptotic bodies by the macrophage system (Figure $1(\mathrm{~d})$ ). The neurons bearing rabies viral antigen failed to show TUNEL positivity in serial sections. In the human brain (6/6 brains), the hippocampus and medulla oblongata revealed occasional TUNEL-labeled inflammatory cells in contrast to canine brain (2/9 cases) (Figure 4(e)).

\section{Discussion}

The formation and maintenance of body form is dependent on apoptosis, a programmed cell death, which is genetically controlled and plays a vital role in both embryonic development and tissue homeostasis in adults [19, 20]. Apoptosis plays a protective role in eliminating virus-infected cells, which might prove harmful if they were to survive. The process of apoptosis has been observed in a multitude of viral infections [21-26], and the number of correlations between viral pathogenesis and apoptosis continue to grow [8, 27]. Some viruses utilize apoptosis as a mechanism to induce cell death, whereas other viruses have clearly exploited the highly regulated apoptotic cascades by blocking it within the cells they reside in to promote their survival in the host environment. RNA viruses multiply rapidly to produce many virions before the host mounts an effective immune response $[28,29]$.

In the recent years, neurotropic viruses in particular have been shown to induce apoptosis within the CNS, 


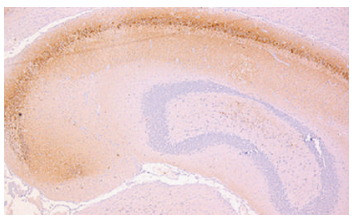

(a)

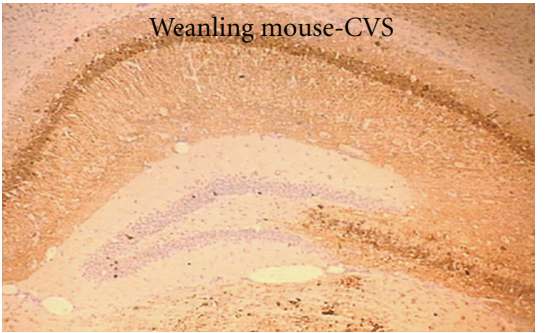

(d)

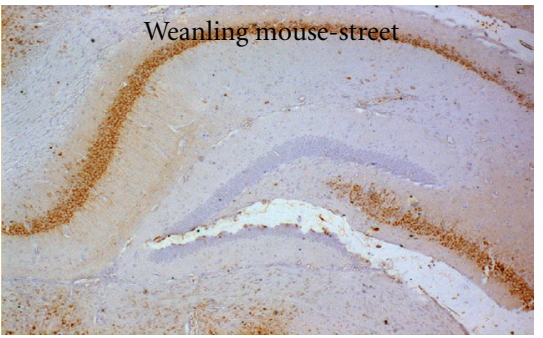

(f)

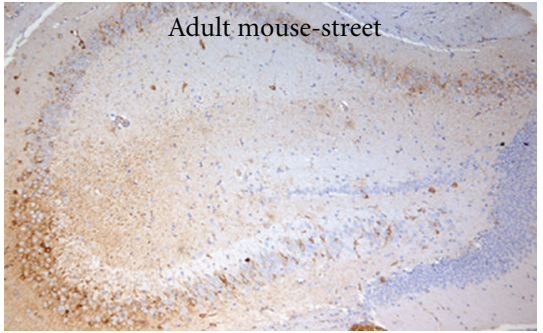

(h)

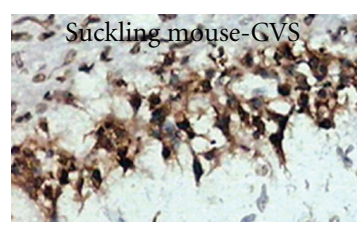

(b)

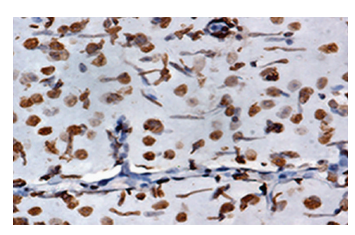

(c)

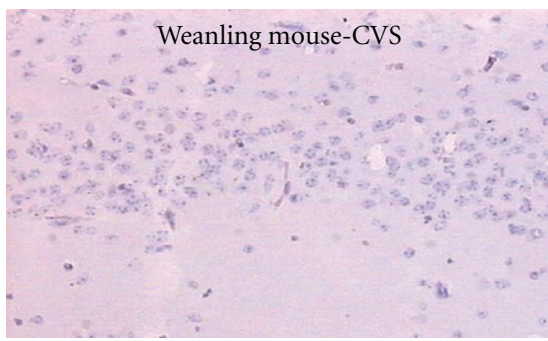

(e)

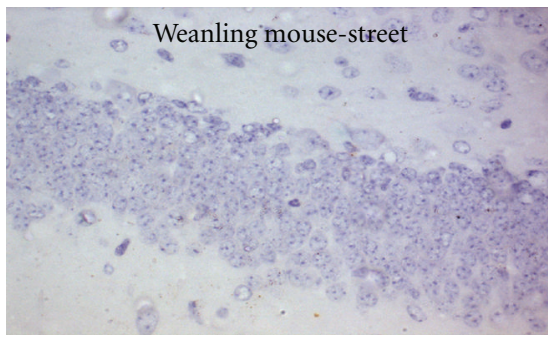

(g)

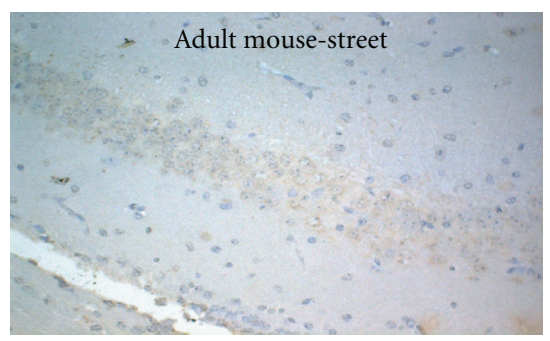

(i)

FIGURE 3: Suckling mouse brain infected with CVS strain of rabies virus shows rabies viral antigen within the pyramidal neurons of hippocampus (a). Infected pyramidal neurons (b) and glial cells (c) reveal apoptosis by TUNEL immunolabeling. Endothelial cells lining vessels are negative. Weanling mouse brain infected intramuscularly with CVS strain of rabies virus (d-e) shows rabies viral antigen pyramidal neurons of hippocampus (d) and absence of TUNEL labeling in these neurons (e). Weanling mouse brain infected intramuscularly with street strain of rabies-virus-labeled neurons in hippocampus (f) and TUNEL labeling is negative (g). Brain from adult mouse infected intramuscularly with street and CVS strain of rabies virus, respectively, labeled the neurons (f, h) but no apoptosis seen by TUNEL technique (g, i).

and depletion of these nonregenerating neuronal cells by apoptosis may result in neurological morbidity [26, 30-32]. This association between viral infection of the CNS and apoptosis has spawned a new area of rabies virus research (Table 3). Researchers initially probed the role of rabiesvirus-induced apoptosis in neuronal and nonneuronal cell lines using attenuated laboratory strains of rabies virus and concluded that a variety of commonly used laboratory strains of rabies virus can indeed induce apoptotic cascades within the cell. Apoptosis was initially documented in rat prostatic adenocarcinoma (AT3) cells infected with a highly neurotropic challenge virus standard (CVS) of rabies virus [12]. Thouloze et al. showed that the ERA (Evelyn
Rotnycki Abelseth) strain of rabies virus (an attenuated strain with restricted cell tropism and nonneuronal cell infection) was able to induce apoptosis in Jurkat T-cells in vitro [33]. The fixed rabies virus strain CVS-11 was found to induce apoptosis of infected mouse neuroblastoma cells, as demonstrated by both DNA laddering as well as TUNELpositive staining of infected cells [34].

Following this, Jackson and coworkers reported induction of widespread neuronal apoptosis and strong TUNEL labeling in laboratory animals (adult and suckling ICR mice) infected intracerebraly with the CVS strain $[12,35]$. Theerasurakarn and Ubol substantiated the presence of apoptosis in CVS-infected suckling mice brain and suggested 


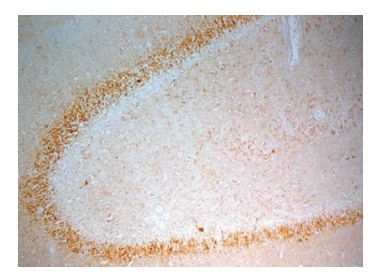

(a)

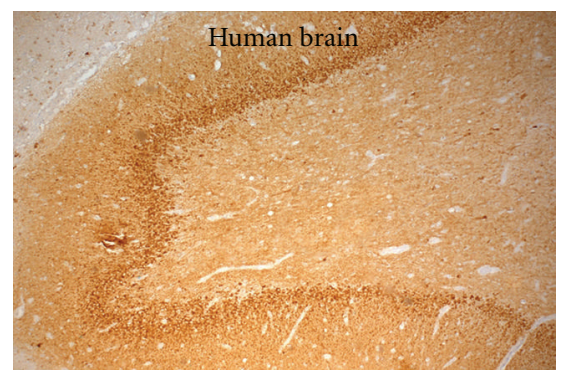

(d)

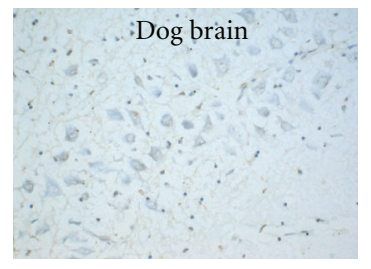

(b)

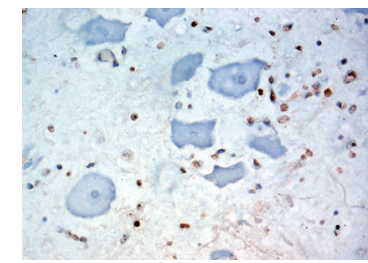

(c)

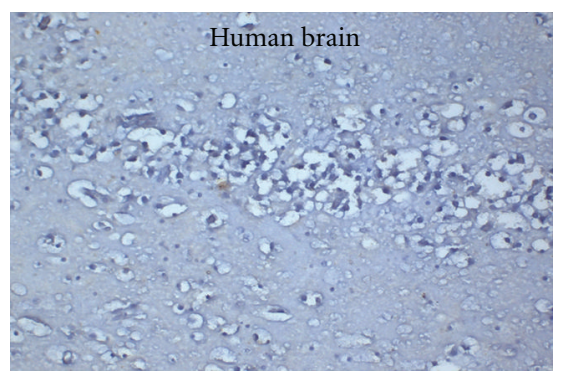

(e)

FIGURE 4: Intense immunolabeling of hippocampal pyramidal cells in canine brain naturally infected with street rabies virus (a) are negative for apoptosis by TUNEL labeling (b). Few inflammatory cells in nuclear area of medulla oblongata are labeled by TUNEL technique (c). No neuronal apoptosis noted in these anatomical areas. Pyramidal neurons in human hippocampus from a case of paralytic rabies infected by street virus showed viral antigen $(d)$ in the absence of TUNEL labeling (e). (a: Immunoperoxidase $x 40$; b: TUNEL $\times 160$; c: TUNEL $\times 400$; D: Immunoperoxidase $\times 40$; E: TUNEL $\times 160$.)

that it was an early event that correlated with disease severity [36]. Examination of brain tissues from Balb/c mice infected with attenuated Pasteur strain of virus (PV), also revealed neuronal apoptosis in both clinically asymptomatic and paralyzed animals.

Mechanism of apoptotic induction has been addressed in few studies. Bax-related, caspase-dependent induction of apoptosis was shown rabies infected neuroblastoma cells [34], along with reactivation of Nedd-2, a developmentally downregulated apoptotic gene and other proapoptotic genes $[37,38]$. But in vivo, although apoptotic cell death has found to be less prominent in bax-deficient mice inoculated with CVS or RV194-2 strains, Jackson detected apoptosis in infected brain stem neurons suggesting that other factors may also play a role [39]. Role of adaptive immunity was investigated but ruled out as apoptosis was demonstrable even in immunodeficient mice as well as in humans $[15,40]$. The extent of neuronal apoptosis in p75 neurotropin receptor mice when compared and wild-type mice inoculated with CVS strain did not show appreciable differences suggesting the lack of direct role in mediating apoptosis [41].

The observations in the present study is in concordance with other studies in suckling mice infected with CVS strain, but neuronal apoptosis was not found in weanling and adult mice. Similarly Jackson and Park had earlier observed that the numbers of apoptotic neurons in the infected suckling mice hippocampus were significantly higher than in the adult mice [35]. The apoptotic cell death in CVS-infected suckling mice but not adults suggest that the developing, immature brain may be more susceptible to apoptotic cell death.

In the present study, the suckling mice inoculated with the CVS strain of rabies virus (IC route) were studied at different time points of the disease process, and apoptosis was detected only in the terminal stage of the illness correlating with severity of infection with progression of the disease. The weanling and adult mice infected with CVS strain of rabies virus (IC and IM) showed no DNA laddering compared to suckling mouse indicating that apoptotic cell loss is not a significant pathogenetic mechanism in causing morbidity in older animals.

The variable results in published literature could be related to differences in virus strain, route of inoculation, or the strain of laboratory animals used and their differential permissiveness. For instance, Scott et al. demonstrated lack of apoptosis in cerebral cortex and hippocampus of six-week-old mice when inoculated with CVS strain peripherally in mediating apoptosis [42]. Earlier studies had documented widespread neuronal apoptosis in mice inoculated by intracerebral route particularly in sucking mice (Table 3) $[35,36,39,40]$. Ubol and Kasisith demonstrated that infection of Swiss albino mice with either a bat strain of rabies virus or a primary isolate from a rabid dog resulted in massive apoptotic cell death in the rodent brain as visualized by TUNEL staining [37], while Yan et al. observed very little TUNEL-positive staining in mice infected with bat rabies virus (SHBRV) despite the clinical signs of disease [14]. Reid and Jackson also failed to observe apoptotic neuronal pathology but recorded TUNEL positive reactivity in inflammatory cells following injection of two variants of CVS 24 strain of rabies, (CVS N2C, and CVS B2C) into bats (which induced significant apoptosis in suckling mice and primary neural cultures) [13]. Thoulouze et al. in in vitro studies demonstrated an inverse correlation between apoptosis and the neurotropic capacity of a virus strain 
TABLE 3: Review of the published literature.

Sl No Author year

Adle-Biassette et al., 1996

[15]

Jackson and Rossiter, 1997 [12]

(3) Thoulouze et al., 1997 [33]

(4)

Ubol et al., 1998 [34]

(5)

Jackson and Park, 1998 [35]

(6)

Theerasurakarn and Ubol, 1998 [36]

Jackson, 1999 [39]

(8)

Jackson and Park, 1999 [41]

(9)

Ubol and Kasisith, 2000

[37]

(10)

Cells or tissue and the viral strain used

Human tissue

Street virus

Cultured rat prostatic

adenocarcinoma

(AT3) cells

Adult ICR mice inoculated intracerebrally with

CVS

Activated murine lymphocytes and the human lymphoblastoid Jurkat T-cell lines

Neuroblastoma cell line

Suckling mice (6-day-old ICR mice)

Suckling mouse brain

Five- to 7-day-old bax-deficient mice and their wild-type littermates

6-day-old p75 neurotrophin receptor-deficient mice and wild-type mice

Adult and suckling mice

Fruit eating adult bats (Artibeus jamaicensis )
Challenge virus standard (CVS) and attenuated strain ERA

CVS 11

Challenge virus standard (CVS) strain of fixed rabies virus, intracerebral inoculation

CVS 11

CVS or the RV194-2 variant of rabies virus inoculated intracerebrally

CVS (Challenge virus standard strain) of fixed rabies virus inoculated intracerebrally

Bat strain and a primary canine rabies virus

CVS-N2c and CVS-B2c (stable variants of CVS-24), inoculated into the right masseter
Conclusion

Apoptosis present or not, if so which cells

Apoptotic neurons identified in the brain stem and hippocampus in the vicinity of inflammatory foci but not in noninflammatory areas

Cultured rat prostatic adenocarcinoma (AT3) cells showed apoptosis (DNA laddering and Bax protein expression). Adult ICR mice showed apoptosis in neurons of hippocampus and cerebral cortex. Apoptosis plays an important role in the pathogenesis of rabies virus infection

(i) Rabies virus infects lymphocytes, (ii) lymphocyte infection with the attenuated ERA rabies virus strain causes apoptosis but not with CVS, and (iii) apoptosis does not hinder rabies virus production. Apoptosis of infected Jurkat T cells was concomitant with viral glycoprotein expression, suggesting that this protein has a role in the induction of apoptosis

Apoptosis present (DNA laddering, TUNEL, caspase $1, \operatorname{Bax})$

Widespread neuronal apoptosis (TUNEL staining, increased Bax expression) in hippocampus and cerebral cortex, in rabies-virus-infected neurons. Apoptosis was more in suckling mice than in adult mice, explaining the greater neurovirulence of rabies virus in younger mice

Apoptosis detected in neurons (TUNEL, DNA fragmentation) and is the earliest death mechanism detected in these mice

Apoptosis was less severe in the cerebral cortex, hippocampus, and cerebellum of the bax-deficient mice compared to wild-type mice

Widespread apoptosis in brain (TUNEL stain)

Expression of Nedd- 2 correlated with the appearance of apoptotic nuclei within the brain. Apoptosis required for elimination of virally infected cells

Apoptosis (DNA fragmentation) not observed in rabies infected neurons with either virus strain 
Table 3: Continued.

\begin{tabular}{|c|c|c|c|c|}
\hline SI No & Author year & $\begin{array}{l}\text { Cells or tissue and } \\
\text { the viral strain used }\end{array}$ & Viral strain & $\begin{array}{l}\text { Conclusion } \\
\text { Apoptosis present or not, if so which cells }\end{array}$ \\
\hline (11) & Yan et al., 2001 [14] & Mice & $\begin{array}{l}\text { Street rabies virus } \\
\text { (silver-haired bat } \\
\text { rabies virus, } \\
\text { SHBRV) and } \\
\text { mouse-adapted } \\
\text { laboratory rabies } \\
\text { virus strain } \\
\text { (CVS-24) }\end{array}$ & $\begin{array}{l}\text { Apoptosis (TUNEL staining) was observed in the } \\
\text { brain with CVS-24-infected mice but not SHBRV } \\
\text { infected mice. Apoptosis is not an essential } \\
\text { pathogenic mechanism for the outcome of street } \\
\text { rabies virus infection }\end{array}$ \\
\hline (12) & $\begin{array}{l}\text { Rutherford and Jackson, } \\
2004[40]\end{array}$ & $\begin{array}{l}\text { Immunodeficient } \\
\text { adult C57BL/6J mice } \\
\text { with nude mice } \\
\text { (T-cell deficient) } \\
\text { and Rag1 mice (T- } \\
\text { and B- cell deficient) }\end{array}$ & $\begin{array}{l}\text { Challenge virus } \\
\text { standard-11 strain } \\
\text { (CVS), intracerebral } \\
\text { inoculation }\end{array}$ & $\begin{array}{l}\text { Neuronal apoptosis prominent in immunodeficient } \\
\text { mice }\end{array}$ \\
\hline (13) & Juntrakul et al., 2005 [49] & $\begin{array}{l}\text { Brain and spinal } \\
\text { cord of } 10 \text { rabies } \\
\text { patients }\end{array}$ & Street virus & $\begin{array}{l}\text { Apoptosis present and correlated with the presence } \\
\text { of rabies virus antigen }\end{array}$ \\
\hline (14) & Sarmento et al., 2005 [45] & $\begin{array}{l}\text { ICR Mice }(4-6 \\
\text { weeks) }\end{array}$ & $\begin{array}{l}\text { Recombinant RVs } \\
\text { with replacement of } \\
\text { G gene, and } \\
\text { wild-type virus } \\
\text { (SHRBV), } \\
\text { intracerebral route } \\
\text { and intramuscular } \\
\text { route }\end{array}$ & $\begin{array}{l}\text { With attenuated RV (IC or IM route), mice showed } \\
\text { prominent inflammation and apoptosis and } \\
\text { inversely correlated with G protein. With wild-type } \\
\text { virus inoculated by IC or IM route, apoptosis was } \\
\text { minimal. Glycoprotein-mediated induction of } \\
\text { apoptosis limits the spread of attenuated rabies } \\
\text { viruses in the central nervous system of mice }\end{array}$ \\
\hline$(15)$ & Ubol et al., 2005 [38] & Neonatal mice & $\begin{array}{l}\text { Street virus, } \\
\text { intracerebral } \\
\text { inoculation }\end{array}$ & Proapoptotic genes upregulated \\
\hline (16) & Jackson et al., 2006 [48] & $\begin{array}{l}\text { Two-day-old ICR } \\
\text { mice inoculated in a } \\
\text { hindlimb thigh } \\
\text { muscle }\end{array}$ & $\begin{array}{l}\text { Recombinant rabies } \\
\text { virus vaccine strain } \\
\text { SAD-L16 (L16) or } \\
\text { SAD-D29 (D29), } \\
\text { which contains an } \\
\text { attenuating } \\
\text { substitution of } \\
\text { Arg333 in the rabies } \\
\text { virus glycoprotein }\end{array}$ & $\begin{array}{l}\text { Less virulent virus was a stronger inducer of } \\
\text { neuronal apoptosis }\end{array}$ \\
\hline (17) & Weli et al., 2006 [11] & $\begin{array}{l}\text { Cultures derived } \\
\text { from the cerebral } \\
\text { cortices and } \\
\text { hippocampi of } \\
\text { 17-day-old mouse } \\
\quad \text { fetuses }\end{array}$ & $\begin{array}{l}\text { CVS strain of rabies } \\
\text { virus }\end{array}$ & $\begin{array}{l}\text { Apoptotic features and activated caspase } 3 \\
\text { expression in cultures. Caspase inhibitors were } \\
\text { neuroprotective }\end{array}$ \\
\hline (18) & Scott et al., 2008 [42] & Six-week-old mice & $\begin{array}{l}\text { CVS strain of fixed } \\
\text { virus inoculated in } \\
\text { the hindlimb } \\
\text { footpad }\end{array}$ & $\begin{array}{l}\text { Few apoptotic cells in the cerebral cortex and } \\
\text { hippocampus. (TUNEL labeling and caspase- } 3 \\
\text { immunostaining) }\end{array}$ \\
\hline (19) & Jackson et al., 2008 [16] & $\begin{array}{l}12 \text { cases of human } \\
\text { rabies (four different } \\
\text { countries) }\end{array}$ & Street virus & $\begin{array}{l}\text { No evidence of neuronal apoptosis (TUNEL } \\
\text { staining) in cerebral cortex, hippocampus, and } \\
\text { brainstem. Caspase- } 3 \text { immunostaining was absent in } \\
\text { neurons, but observed in microglial processes }\end{array}$ \\
\hline$(20)$ & Suja et al., 2009 [17] & 10 canine brains & Street virus & No neuronal apoptosis (DNA laddering) \\
\hline
\end{tabular}


in human lymphoblastoid Jurkat $\mathrm{T}$ cell lines and proposed that blockage of apoptosis could be a strategy evolved by neurotropic virus to favor its neuroinvasiveness [43]. Baloul and Lafon in an in vivo study compared the apoptotic properties of neurotropic CVS strain with nonneurotropic vaccine strains like PV and suggested that $\mathrm{T}$ cell mediated apoptosis of neuronal cells in the PV-infected brain prevented virus propagation in the brain [44]. Lack of apoptosis in mice inoculated with wild-type virus (SHBRV) in comparison with attenuated strains was highlighted by Sarmento and coworkers [45] Other viral factors such as glycoprotein expression have been shown to influence pathogenicity of different rabies virus variants and correlate inversely with apoptosis [45-47]. Jackson et al. using recombinant vaccine strain SAD-L16 (L16) or SAD-D29 (D29), which has an attenuating substitution of Arg333 in the viral glycoprotein, demonstrated that the less neurovirulent strains of rabies virus are stronger inducers of neuronal apoptosis [48].

Apoptosis was not detectable in our study when street virus strain was inoculated (IC or IM) into both suckling and adult mice in our study. Due to the long incubation period with the street virus, the suckling mice were almost weanling, by the time they manifested symptoms (12-15 days) of the disease, underscoring the age dependence of the apoptotic phenomenon to cells in the immature brain. Yan et al. also demonstrated the conclusively presence of apoptosis in brains of CVS-24-infected mice but not street virus- (silver-haired bat rabies virus-) infected mice [14]. The number of studies using street virus strain of rabies is limited [14-17, 38, 49] (Table 3). Yan et al. was first to demonstrate lack of apoptosis in mice inoculated with silverhaired bat rabies virus [14]. Jackson et al. convincingly demonstrated that there is no role for neuronal apoptosis in mortality in rabies in natural infection in humans by street viral strain [16]. Two studies have, however, shown presence of apoptosis in humans $[15,49]$. The immunocompromised state (HIV-1 positive) of the host, in the case described by Adle Biassette et al. [15], could have induced apoptosis as previously demonstrated in immunodeficient experimental mice [40]. Juntrakul and coworkers in ten cases of human rabies demonstrated apoptosis in spinal cord [49]. Other workers have not replicated this, and the authors themselves suggest that the occurrence of apoptosis diffusely throughout the neuraxis could have been contributed by other factors such as hypoxia and ischemia occurring preterminally. Conspicuous lack of neuronal apoptosis in our previous study on canine brains [17] and the present study concurs with that of Jackson and coworkers [16].

The occurrence of apoptosis resulting from infection with a "street rabies" virus strain was restricted to inflammatory cells but not virus-infected neurons; thus it may not be responsible for mortality of the host [16].

In the natural infection by the rabies virus as observed in the present study, in human, canine, and mice inoculated with street rabies via intramuscular route, neuronal apoptosis was minimal and inconsequential despite the widespread presence of rabies virus in almost all neuroanatomical areas of the brain examined. The street virus has, therefore, evolved very efficient measures to prevent neuronal death by blocking apoptosis, thereby promoting widespread and efficient neuroinvasion by the virus.

\section{Conclusion}

Prevention of neuronal apoptosis appears to be a subversive strategy developed by the street strain of rabies virus to evade elimination and promote persistent nonlethal infectious cycle, ensuring the long-term survival of the rabies virus in the host. This could account for longer incubation period noted in higher animals. In addition, our observations suggest that street virus triggers apoptosis in inflammatory cells, thereby interfering with release of cytotoxic cytokines and preventing cell lysis. Further studies on the molecular mechanisms, utilized by the rabies virus to prevent apoptosis, will shed light on the pathobiology of rabies viral infection and thereby explain the cause of fatality in these cases.

\section{Acknowledgments}

The authors would like to gratefully acknowledge the financial support extended by the Indian Council of Medical Research (ICMR), the Government of India for providing the Research Fellowship to pursue this work, and the Human Brain Tissue Repository (Human Brain Bank) for providing very valuable human brain tissue for the study. Technical help provided by Mr. K. Manjunath for assistance with photographic illustration, Mrs. Rajashakthi,and Mr Shivaji Rao is acknowledged. Secretarial assistance of Mrs. Kanakalakshmi and Mrs. Manjula Madan is gratefully acknowledged.

\section{References}

[1] WHO, Expert Consultation on Rabies, Technical Report Series 931, WHO, Geneva, Switzerland, 2005.

[2] M. K. Sudarshan, S. N. Madhusudana, B. J. Mahendra et al., "Assessing the burden of human rabies in India: results of a national multi-center epidemiological survey," International Journal of Infectious Diseases, vol. 11, no. 1, pp. 29-35, 2007.

[3] B. Dietschold, C. E. Rupprecht, Z. F. Fu, and H. Koprowski, "Rhabdo virus," in Fields Virology, B. Fields, D. Knipe, P. M. Howley et al., Eds., pp. 1137-1159, Lippincott-Raven, Philadelphia, Pa, USA, 3rd edition, 1996.

[4] D. G. Constantine, "Rabies transmission by nonbite route," Public Health Reports, vol. 77, pp. 287-289, 1962.

[5] T. Hemachudha, "Human rabies: clinical aspects, pathogenesis, and potential therapy," Current Topics in Microbiology and Immunology, vol. 187, pp. 122-143, 1993.

[6] Z. F. Fu and A. C. Jackson, "Neuronal dysfunction and death in rabies virus infection," Journal of NeuroVirology, vol. 11, no. 1, pp. 101-106, 2005.

[7] D. E. Bredesen, "Neural apoptosis," Annals of Neurology, vol. 38, no. 6, pp. 839-851, 1995.

[8] E. S. Razvi and R. M. Welsh, "Apoptosis in viral infections," Advances in Virus Research, vol. 45, pp. 1-60, 1995. 
[9] C. B. Thompson, "Apoptosis in the pathogenesis and treatment of disease," Science, vol. 267, pp. 1456-1462, 1995.

[10] J. M. Hardwick and D. E. Griffin, "Viral effects on cellular functions," in Viral Pathogenesis, N. Nathanson, R. Ahmed, F. G. Searano et al., Eds., pp. 55-83, Lippincott-Raven, Philadelphia, Pa, USA, 1997.

[11] S. C. Weli, C. A. Scott, C. A. Ward, and A. C. Jackson, "Rabies virus infection of primary neuronal cultures and adult mice: failure to demonstrate evidence of excitotoxicity," Journal of Virology, vol. 80, no. 20, pp. 10270-10273, 2006.

[12] A. C. Jackson and J. P. Rossiter, "Apoptosis plays an important role in experimental rabies virus infection," Journal of Virology, vol. 71, no. 7, pp. 5603-5607, 1997.

[13] J. E. Reid and A. C. Jackson, "Experimental rabies virus infection in Artibeus jamaicensis bats with CVS-24 variants," Journal of NeuroVirology, vol. 7, no. 6, pp. 511-517, 2001.

[14] X. Yan, M. Prosniak, M. T. Curtis et al., "Silver-haired bat rabies virus variant does not induce apoptosis in the brain of experimentally infected mice," Journal of NeuroVirology, vol. 7, no. 6, pp. 518-527, 2001.

[15] H. Adle-Biassette, H. Bourhy, M. Gisselbrecht et al., "Rabies encephalitis in a patient with AIDS: a clinicopathological study," Acta Neuropathologica, vol. 92, no. 4, pp. 415-420, 1996.

[16] A. C. Jackson, E. Randle, G. Lawrance, and J. P. Rossiter, "Neuronal apoptosis does not play an important role in human rabies encephalitis," Journal of NeuroVirology, vol. 14, no. 5, pp. 368-375, 2008.

[17] M. S. Suja, A. Mahadevan, S. N. Madhusudhana, S. K. Vijayasarathi, and S. K. Shankar, "Neuroanatomical mapping of rabies nucleocapsid viral antigen distribution and apoptosis in pathogenesis in street dograbies - an immunohistochemical study," Clinical Neuropathology, vol. 28, no. 2, pp. 113-124, 2009.

[18] K. Morimoto, D. C. Hooper, H. Carbaugh, Z. F. Fu, H. Koprowski, and B. Dietzschold, "Rabies virus quasispecies: implications for pathogenesis," Proceedings of the National Academy of Sciences of the United States of America, vol. 95, no. 6, pp. 3152-3156, 1998.

[19] E. White, "Life, death, and the pursuit of apoptosis," Genes and Development, vol. 10, no. 1, pp. 1-15, 1996.

[20] D. L. Vaux and A. Strasser, "The molecular biology of apoptosis," Proceedings of the National Academy of Sciences of the United States of America, vol. 93, no. 6, pp. 2239-2244, 1996.

[21] L. M. Esolen, S. W. Park, J. M. Hardwick, and D. E. Griffin, "Apoptosis as a cause of death in measles virus-infected cells," Journal of Virology, vol. 69, no. 6, pp. 3955-3958, 1995.

[22] V. S. Hinshaw, C. W. Olsen, N. Dybdahl-Sissoko, and D. Evans, "Apoptosis: a mechanism of cell killing by influenza A and B viruses," Journal of Virology, vol. 68, no. 6, pp. 3667-3673, 1994.

[23] T. Takizawa, S. Matsukawa, Y. Higuchi, S. Nakamura, Y. Nakanishi, and R. Fukuda, "Induction of programmed cell death (apoptosis) by influenza virus infection in tissue culture cells," Journal of General Virology, vol. 74, no. 11, pp. 23472355, 1993.

[24] S. H. Jeurissen, F. Wagenaar, J. M. Pol, A. J. van der Eb, and M. H. M. Noteborn, "Chicken anemia virus causes apoptosis of thymocytes after in vivo infection and of cell lines after in vitro infection," Journal of Virology, vol. 66, no. 12, pp. 7383 7388, 1992.
[25] E. A. Tolskaya, L. I. Romanova, M. S. Kolesnikova et al., "Apoptosis-inducing and apoptosis-preventing functions of poliovirus," Journal of Virology, vol. 69, no. 2, pp. 1181-1189, 1995.

[26] S. M. Oberhaus, T. S. Dermody, and K. L. Tyler, "Apoptosis and the cytopathic effects of reovirus," Current Topics in Microbiology and Immunology, vol. 233, pp. 23-49, 1998.

[27] J. G. Teodoro and P. E. Branton, "Regulation of apoptosis by viral gene products," Journal of Virology, vol. 71, no. 3, pp. 1739-1746, 1997.

[28] A. H. Koyama, "Induction of apoptotic DNA fragmentation by the infection of vesicular stomatitis virus," Virus Research, vol. 37, no. 3, pp. 285-290, 1995.

[29] M. Kurokawa, A. H. Koyama, S. Yasuoka, and A. Adachi, "Influenza virus overcomes apoptosis by rapid multiplication," International Journal of Molecular Medicine, vol. 3, no. 5, pp. 527-530, 1999.

[30] J. Lewis, S. L. Wesselingh, D. E. Griffin, and J. M. Hardwick, "Alphavirus-induced apoptosis in mouse brains correlates with neurovirulence," Journal of Virology, vol. 70, no. 3, pp. 1828-1835, 1996.

[31] X. H. Liang, L. K. Kleeman, H. H. Jiang et al., "Protection against fatal sindbis virus encephalitis by Beclin, a novel Bcl2 -interacting protein," Journal of Virology, vol. 72, no. 11, pp. 8586-8596, 1998.

[32] A. Pekosz, J. Phillips, D. Pleasure, D. Merry, and F. GonzalezScarano, "Induction of apoptosis by La Crosse virus infection and role of neuronal differentiation and human bcl-2 expression in its prevention," Journal of Virology, vol. 70, no. 8, pp. 5329-5335, 1996.

[33] M. I. Thoulouze, J. P. Rossiter, J. A. Montano-Hirose, and M. Lafon, "Rabies virus infects mouse and human lymphocytes and induces apoptosis," Journal of Virology, vol. 71, pp. 56035607, 1997.

[34] S. Ubol, C. Sukwattanapan, and P. Utaisincharoen, "Rabies virus replication induces Bax-related, caspase dependent apoptosis in mouse neuroblastoma cells," Virus Research, vol. 56, no. 2, pp. 207-215, 1998.

[35] A. C. Jackson and H. Park, "Apoptotic cell death in experimental rabies in suckling mice," Acta Neuropathologica, vol. 95, no. 2, pp. 159-164, 1998.

[36] S. Theerasurakarn and S. Ubol, "Apoptosis induction in brain during the fixed strain of rabies virus infection correlates with onset and severity of illness," Journal of Neuro Virology, vol. 4, no. 4, pp. 407-414, 1998.

[37] S. Ubol and J. Kasisith, "Reactivation of Nedd-2, a developmentally down-regulated apoptotic gene, in apoptosis induced by a street strain of rabies virus," Journal of Medical Microbiology, vol. 49, no. 11, pp. 1043-1046, 2000.

[38] S. Ubol, J. Kasisith, D. Pitidhammabhorn, and V. Tepsumethanol, "Screening of pro-apoptotic genes upregulated in an experimental street rabies virus-infected neonatal mouse brain," Microbiology and Immunology, vol. 49, no. 5, pp. 423431, 2005.

[39] A. C. Jackson, "Apoptosis in experimental rabies in baxdeficient mice," Acta Neuropathologica, vol. 98, no. 3, pp. 288294, 1999.

[40] M. Rutherford and A. C. Jackson, "Neuronal apoptosis in immunodeficient mice infected with the challenge virus standard strain of rabies virus by intracerebral inoculation," Journal of NeuroVirology, vol. 10, no. 6, pp. 409-413, 2004.

[41] A. C. Jackson and H. Park, "Experimental rabies virus infection of p75 neurotrophin receptor-deficient mice," Acta Neuropathologica, vol. 98, no. 6, pp. 641-644, 1999. 
[42] C. A. Scott, J. P. Rossiter, R. D. Andrew, and A. C. Jackson, "Structural abnormalities in neurons are sufficient to explain the clinical disease and fatal outcome of experimental rabies in yellow fluorescent protein-expressing transgenic mice," Journal of Virology, vol. 82, no. 1, pp. 513-521, 2008.

[43] M. I. Thoulouze, M. Lafage, V. J. Yuste et al., "Apoptosis inversely correlates with rabies virus neurotropism," Annals of the New York Academy of Sciences, vol. 1010, pp. 598-603, 2003.

[44] L. I. Baloul and M. Lafon, "Apoptosis and rabies virus neuroinvasion,” Biochimie, vol. 85, no. 8, pp. 777-788, 2003.

[45] L. Sarmento, X. Q. Li, E. Howerth, A. C. Jackson, and Z. F. Fu, "Glycoprotein-mediated induction of apoptosis limits the spread of attenuated rabies viruses in the central nervous system of mice," Journal of NeuroVirology, vol. 11, no. 6, pp. 571-581, 2005.

[46] K. Morimoto, D. C. Hooper, S. Spitsin, H. Koprowski, and B. Dietzschold, "Pathogenicity of different rabies virus variants inversely correlates with apoptosis and rabies virus glycoprotein expression in infected primary neuron cultures," Journal of Virology, vol. 73, no. 1, pp. 510-518, 1999.

[47] S. Lay, C. Préhaud, B. Dietzschold, and M. Lafon, "Glycoprotein of nonpathogenic rabies viruses is a major inducer of apoptosis in human jurkat T cells," Annals of the New York Academy of Sciences, vol. 1010, pp. 577-581, 2003.

[48] A. C. Jackson, P. Rasalingam, and S. C. Weli, "Comparative pathogenesis of recombinant rabies vaccine strain SAD-L16 and SAD-D29 with replacement of Arg333 in the glycoprotein after peripheral inoculation of neonatal mice: less neurovirulent strain is a stronger inducer of neuronal apoptosis," Acta Neuropathologica, vol. 111, no. 4, pp. 372-378, 2006.

[49] S. Juntrakul, P. Ruangvejvorachai, S. Shuangshoti, S. Wacharapluesadee, and T. Hemachudha, "Mechanisms of escape phenomenon of spinal cord and brainstem in human rabies," BMC Infectious Diseases, vol. 16, no. 5, article 104, 2005. 


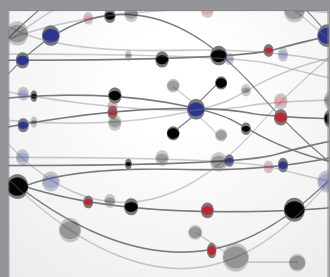

The Scientific World Journal
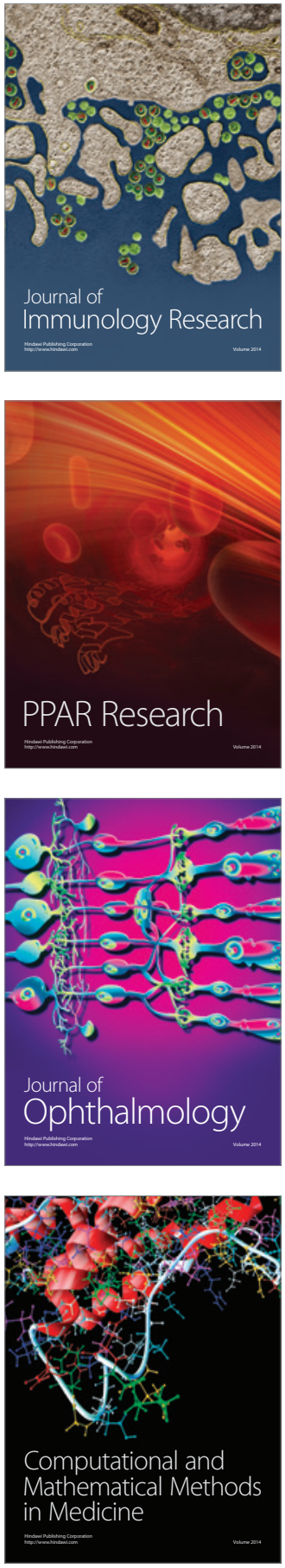

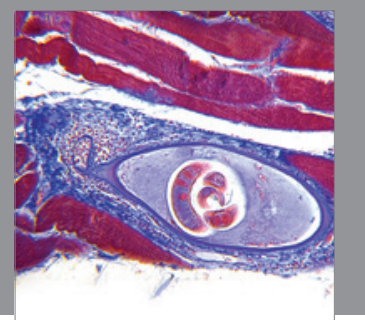

Gastroenterology

Research and Practice
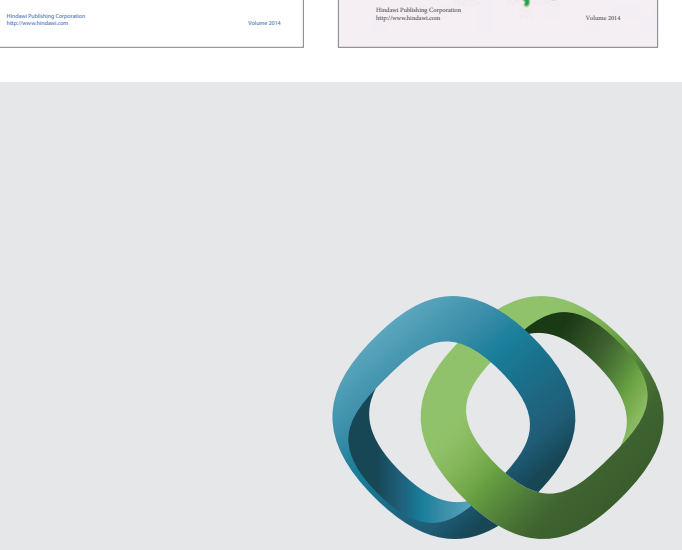

\section{Hindawi}

Submit your manuscripts at

http://www.hindawi.com
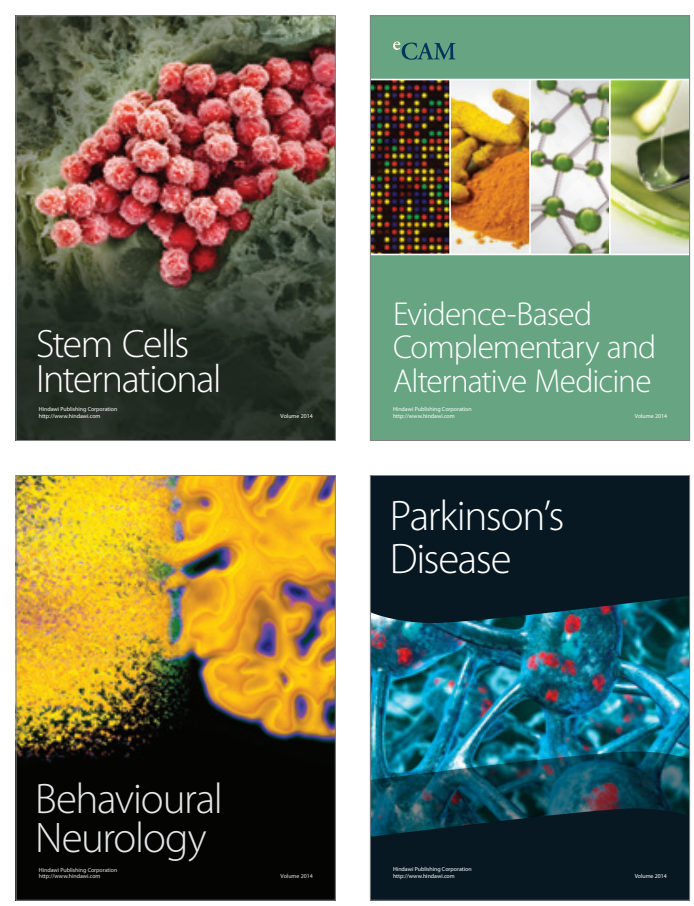

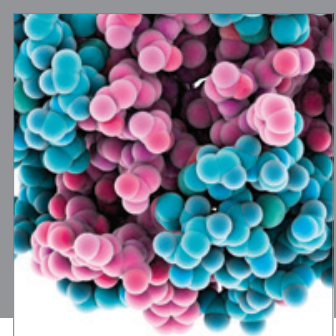

Journal of
Diabetes Research

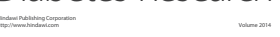

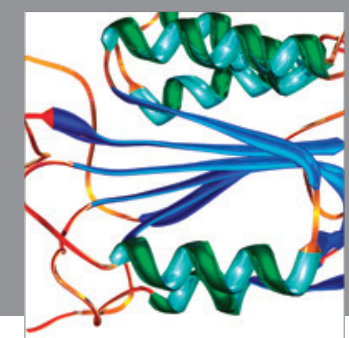

Disease Markers
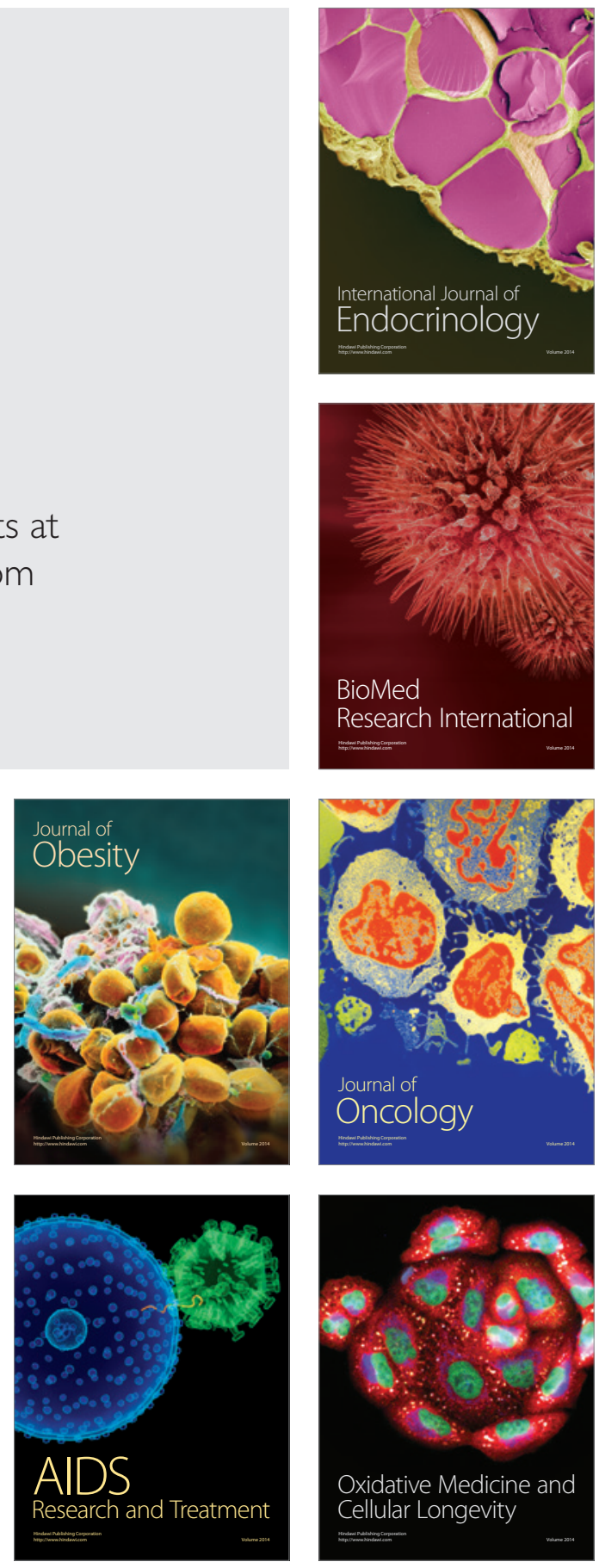